\title{
Selected factors affecting seedling recruitment of dalmatian toadflax
}

\author{
MATTHEW J. GRIESHOP AND ROBERT M. NOWIERSKI
}

Authors are Graduate Research Assistant, Department of Entomology, Kansas State University, Manhattan, Kans. 66507 and National Program Leader, Bio-Based Pest Management, USDA-CREES-PAS, 1400 Independence Ave., SW; Washington, DC 20250-2220. At the time of the research, the senior author was a Graduate Research Assistant, Department of Entomology, Montana State University, Bozeman, Mont. 59717-3020 the second author was Professor, Department of Entomology, Montana State University, Bozeman, Mont. 59717-3020.

Abstract

Seedling recruitment of Dalmatian toadflax, (Linaria genistifolia ssp. dalmatica (L.) Maire and Petitmengin (Scrophulariaceae)), was examined in a 2-year field study in Montana using overseeding and plant/insect exclusion methods, to determine whether it was more limited by seed availability or interspecific plant competition. Overseeding test plots with toadflax seed had no effect on seedling recruitment. Exclusion of plant competition (via herbicide application and pruning) significantly increased total, and cumulative seedling recruitment of Dalmatian toadflax on the last sampling date in 3 of 4 , and 2 of 4 cases examined, respectively. Insect exclusion (via insecticide application) significantly increased total seedling recruitment of Dalmatian toadflax on the last sampling date in only 1 of 4 cases examined, and had no effect on cumulative seedling recruitment of Dalmatian toadflax on the last sampling date. We conclude that seedling recruitment in Dalmatian toadflax was more strongly influenced by plant competition than herbivory in our study. Hence, microsite limitation (i.e., competition for "safe sites for germination") rather than seed limitation appears to play a more important role in toadflax seedling recruitment. In light of this, current biological control agents that impact seed production will likely have minimal capabilities of influencing toadflax density. Thus, a premium should be placed on establishing biological control agents that are able to cause significant damage to the stem and root system of Dalmatian toadflax, and in maintaining a healthy plant community that, through interspecific competition, will negatively affect toadflax seedling recruitment.

Key Words: seed limitation, microsite, weed management, biological control, rangeland, ecology, overseeding, Brachypterolus pulicarius, plant competition, Linaria genistifolia, ssp. Dalmatica

Dalmatian toadflax, (Linaria genistifolia ssp. dalmatica (L.) Maire and Petitmengin (Scrophulariaceae)), is an introduced plant of Mediterranean origin that has become a serious weed of recreation and rangelands in Montana and other Northwestern states (Alex 1962, Nowierski 1995, 1996). The plant is characterized by yellow snapdragon-like flowers, spherical seed capsules,

Research was funded in part by The Blackfoot Challenge, Bureau of Indian affairs, and the Bureau of Land Management. Authors wish to thank Wendell Morrill, David Weaver, and Xinzhi Ni for their helpful comments on an earlier draft of this manuscript.

Manuscript accepted 3 Jan. 02.
Resumen

El establecimiento de plántulas de "Dalmatian toadflax", Linaria genistifolia ssp. dalmatica (L.) "Maire" y "Petitmengin" (Scrophulariaceae), se examinó en un estudio de campo de 2 años realizado en Montana a través del uso de métodos de sobresiembra y de exclusión a planta/insectos, para determinar si es establecimiento de plántulas fue mas limitado por la disponibilidad de semilla o por competencia interespecifica. La sobresiembra de las parcelas de prueba con semilla de "Toadfax" no tuvo efecto en el establecimiento de plántulas. La exclusión de competencia entre plantas (vía aplicación de herbicidas y poda) incrementó significativamente el establecimiento total y acumulativo de plántulas de "Dalmatian toadflax"en la última fecha de muestreo en 3 de 4 y 2 de 4 casos examinados respectivamente. La exclusión de insectos (vía aplicación de insecticida) incremento significativamente el establecimiento total de plántulas de " Dalmatian toadflax"en la última fecha de muestreo de solo 1 de 4 casos examinados y no tuvo efecto en el establecimiento acumulativo de plántulas de "Dalmatian toadflax"en la última fecha de muestreo. Concluimos, que en nuestro estudio, el establecimiento de plántulas de "Dalmatian toadflax"fue mas fuertemente afectado por la competencia entre plantas que por la herbivoría. Entonces, la disponibilidad limitada de micrositios (esto es, la competencia por sitios seguros para germinación), mas que la disponibilidad limitada de semilla, parece jugar un papel más importante en el establecimiento de plántulas de "Toadflax". A la luz de esto, los agentes de control biológico actuales que impactan la producción de semilla probablemente tendrán un mínima capacidad de influir en la densidad de "Toadflax". Así, se debe poner especial atención en establecer agentes de control biológico que sean capaces de causar un daño significativo al sistema de raíz y tallo del "Dalmatian toadflax"y en mantener una comunidad vegetal saludable, que a través de competencia interespecifica, afectará negativamente el establecimiento de plántulas de "Toadflax".

glaucous green foliage, a deep taproot, and lateral root system. A single mature plant is capable of producing half a million seeds per growing season (Lajeunesse et al. 1993). Seeds remain viable in the soil for as long as 10 years resulting in high levels of accumulation in the seed bank (Robocker 1970, 1974). In addition to causing disruption of the plant community through displacement of native vegetation, Dalmatian toadflax contains a number of defensive compounds (Jeanneret and Schroeder 1992) and as such is reportedly toxic to livestock and wildlife (Polunin 1969). 
Chemical and cultural management of Dalmatian toadflax has generally been ineffective due to the perennial nature of the weed, its waxy foliage, a deep taproot, and the low economic return associated with recreation and rangelands (Lajenunesse et al. 1993).

Brachypterolus pulicarius (L.) (Nitidulidae) is a biological control agent that directly affects the sexual reproductive capacity of Dalmatian toadflax. The ovary-feeding beetle occurs adventively in North America. B. pulicarius larvae feed on pollen, anthers, ovaries, and maturing seed of Dalmatian toadflax, and in the process may cause seed capsule abortion (Nowierski 1996, Grubb 1998). Grubb (1998) has shown that B. pulicarius is capable of reducing seed production in Dalmatian toadflax by up to $93 \%$.

At present, it is unclear whether biological control agents that attack reproductive structures of Dalmatian toadflax will have a tangible effect on plant density in established stands. Whether or not Dalmatian toadflax can be managed using natural enemies that attack reproductive tissues likely depends on whether Dalmatian toadflax is a seed-limited versus micrositelimited plant.

Both the availability of seed and the availability of microsites limit the recruitment of new plants into a population (Eriksson and Ehlen 1991). Seed-limited plants generally produce a lower ratio of seeds to microsite, while microsite-limited plants have a higher ratio of seeds to microsite. While recruitment is usually dependent on a combination of both of these factors, in many instances it should be possible to determine which factor plays the dominant role in determining seedling recruitment in specific instances.

For the purpose of this study microsite was defined as a confluence of water, nutrient, and light availability. As Dalmatian toadflax has a tendency to inhabit sites characterized by well-drained soils and this study took place in arid environments, water was quite likely the single most important factor in determining microsites safe for seedling recruitment. Previous studies have shown that Dalmatian toadflax seedling demonstrate poor interspecific competitive ability for soil moisture (Robocker 1970, 1974).

Studies on the effects of inflorescence feeding insects on seedling recruitment of plants have shown that seed predation by insects can have a dramatic effect on seedling recruitment, or little to no effect at all. Extensive experimentation by Louda et al. (1990) and Louda and Potvin
(1995) in the Nebraska sand hills prairie has shown that recruitment of the Platt thistle, Cirsium canescens (Nutt.), is severely limited by insect seed predators. Seedling recruitment also was found to be limited by seed predation in the perennial shrub Haploppappus squarrosus (Hall) (Louda 1982), and in wild parsnip, Pastinaca sativa (L.) (Hendrix and Trapp 1989). In contrast, for other plant species such as Senacio jacoboaea (L.) and Cytisus scoparius (L.), seedling recruitment was not reduced by insect herbivory (Crawley and Gillman 1989), nor by seed predation (Bossard and Rejmanek 1994).

Interspecific plant competition may affect the availability of microsites for seedling emergence, which in turn may effectively limit seedling recruitment. Putwain and Harper (1968) showed that recruitment of Rumex acetosella (L.) in established grasslands was entirely dependent on reduced grass competition. Similarly, Opuntia Fragilis (Haw.) has been shown to have a higher rate of recruitment when interspecific competition is excluded (Burger and Louda 1995). In another study, initial recruitment of several biennial plants was shown to be inversely correlated with levels of ground cover (Gross and Werner 1982).

Robocker (1970) reported that a single vigorous adult toadflax plant was capable of producing half a million seeds per growing season, $76 \%$ of which germinated when between $1-5$ years of age and stored at room temperature. In addition to being prolific seed producers mature Dalmatian toadflax plants have been described as possessing an impressive root system consisting both of a taproot as well as lateral roots from which prostrate vegetative stems are produced. Vegetative stems have been described as forming "fairy rings" around parent plants, which may persist after parent plants have dropped out of the population (Vujnovic and Wein 1997).

Given the prolific seed production of Dalmatian toadflax and its ability to reproduce vegetatively we hypothesized that, in situations where seed predation is not a factor and plant competition is negligible, seedling recruitment of Dalmatian toadflax will not be seed limited. Whether or not it might be limited under high levels of seed predation and/or plant competition was a more complex question. Given the poor competitive ability of Dalmatian toadflax seedlings for soil moisture, and under competition from forbs and grasses, it seems reasonable to expect seedling recruitment to be limited by micro-site availability (Robocker 1970, 1974). To test whether or not Dalmatian toadflax was seed limited in the presence or absence of seed predation and interspecific plant competition, a combination of field and experimental studies were carried out during the summers of 1997 and 1998.

\section{Materials and Methods}

\section{Experimental design}

The field experimental layout for 1997 consisted of a fixed block, split-split plot, factorial design with 4 treatments randomly assigned over 4 blocks at 2 sites in Montana. For the first factor interspecific, above ground plant competition was allowed versus excluded, while insect seed herbivory was allowed or excluded for the second factor.

In 1998 a third factor (overseeded versus non-overseeded) was added to the experimental design at the 2 field sites, resulting in a 3-factor design with 8 treatments and 4 blocks. The 2 sites chosen for this study had received previous releases of $B$. pulicarius. Four blocks were established at the 2 research sites to block against obvious differences in vegetative cover.

\section{Site and block descriptions}

The study took place during the 1997 and 1998 growing seasons. The first site was located on the Crow Indian Reservation, $20 \mathrm{~km}$ North of Wyola, Big Horn County, Montana, (Latitude $45^{\circ} 5^{\prime}$, Longitude $107^{\circ} 40^{\prime}$, approximate elevation 1,131 meters), hereafter referred to as the Wyola site. The second site was located adjacent to the Canyon Ferry Reservoir approximately $16 \mathrm{~km} \mathrm{SE}$ of Helena, Broadwater County, Montana (Latitude $49^{\circ} 39^{\prime}$, Longitude $111^{\circ} 44^{\prime}$, approximate elevation 1,211 meters), hereafter referred to as the Canyon Ferry site. Sites were chosen because they reflected different habitat types infested with Dalmatian toadflax and both sites had had previous releases of Brachypterolus pulicarius for at least 8 years. The number of Brachypterolus pulicarius released at the Wyola site during the summers of 1994 , 1995 , and 1996 was 100,675 , and 0 individual beetles, respectively. The number of Brachypterolus pulicarius released at the Canyon Ferry site during the summers of 1994, 1995, and 1996 was 100, 200, and 300 individual beetles, respectively (Nowierski unpublished data).

Each site consisted of 4 blocks with 8 treatments representing 8 possible combinations of experimental factors. Blocks were fixed previous to treatment assign- 
Table 1. Pre-treatment mean ( \pm standard error) Dalmatian toadflax stem counts, Dalmatian toadflax percent cover, other plant species percent cover and bare ground percent cover by blocks at either site 1997.

\begin{tabular}{lcccc}
\hline \hline Block & $\begin{array}{c}\text { Number Dalmatian } \\
\text { toadflax stems }\end{array}$ & $\begin{array}{c}\text { Dalmatian } \\
\text { toadflax cover }\end{array}$ & Other plant cover & Bare ground \\
\hline & $\begin{array}{c}\text { (No.) } \\
\text { Canyon Ferry }\end{array}$ & $(\%)$ & $(\%)$ & $(\%)$ \\
1 & $15.5 \pm 1.3$ & $7.9 \pm 0.4$ & $85.8 \pm 1.6$ & $6.4 \pm 1.6$ \\
2 & $9.4 \pm 0.8$ & $20.8 \pm 4.4$ & $72.5 \pm 3.9$ & $6.8 \pm 1.8$ \\
3 & $14.5 \pm 1.0$ & $9.1 \pm 1.1$ & $36.4 \pm 4.1$ & $54.5 \pm 4.6$ \\
4 & $13.8 \pm 0.9$ & $7.3 \pm 0.5$ & $29.4 \pm 2.4$ & $63.4 \pm 2.7$ \\
& & & & \\
1 & Wyola & & & \\
2 & $25.8 \pm 1.7$ & $12.4 \pm 1.5$ & $48.9 \pm 6.1$ & $38.8 \pm 6.1$ \\
3 & $18.3 \pm 1.5$ & $11.3 \pm 1.1$ & $14.9 \pm 1.7$ & $73.9 \pm 2.3$ \\
4 & $26.5 \pm 1.2$ & $12.9 \pm 1.1$ & $49.9 \pm 4.1$ & $37.3 \pm 3.7$ \\
\hline
\end{tabular}

ment through the use of Dalmatian toadflax stem counts, Dalmatian toadflax percent cover, and total plant cover measurements across a spatial gradient (Table 1). The experiment was laid out in a randomized fashion across the fixed block design, with each treatment occurring once in each block. Replicates of each of the 8 factor/treatment (1998) combinations were positioned within each block through the use of permanent quadrats.

The Wyola site had a higher density of Dalmatian toadflax plants than the Canyon Ferry site in addition to having a long history of cattle grazing. Cattle and horses were present at the Wyola site during both study seasons. The area where the plots were laid out, and where toadflax density was highest was an old unfilled gravel pit. Soil surface texture at the Wyola site ranged from sandy loam to sandy clay loam with a mean organic matter content of $1.29 \%$, and a mean water holding capacity of $9.28 \%$ at 15 bars. Blocking was laid out across a basin, up a north-facing slope, along the top of a slight hill, and then down a south-facing slope, with each described region receiving a single block of randomly assigned treatments. Other plants occurring at the study site included downy brome (Bromus tectorum L.), yucca (Yucca glauca Nutt.), ragweed (Ambrosia artemisiifolia L.), western salsify (Tragopogon dubius Scop.), and yellow sweet clover (Melilotus officinalis (L) Lam).

The site located at Canyon Ferry was markedly different than the Wyola site and consisted of a hillside adjacent to the BLM's Riverside Campground. Grazing pressure at the Canyon Ferry site consisted of only occasional browsing by white-tail and mule deer. Soil surface texture oil at the Canyon Ferry site ranged from sandy clay loam to loam with a mean organic matter content of $3.15 \%$, and a mean water holding capacity of $8.73 \%$ at 15 bars. Environmental conditions were somewhat cooler than at the Wyola site with frequent thunderstorms. Blocking was laid across the flat before a hillside and then in 3 progressively decreasing plant cover levels up the hillside. Each described region received a single block of treatments. Other plants occurring at the study site included downy brome, prickly pear (Opuntia polyacantha Haw.), yellow sweet clover, leafy spurge (Euphorbia esula L.), and spotted knapweed (Centaurea maculosa Lam.).

\section{Quadrat frame construction and sampling procedure}

Seedling recruitment, plant cover data and seed production rates were collected using 4 blocks of $8,60 \times 60 \mathrm{~cm}$, permanent quadrats at both sites. Thirty-two similar clusters of adult Dalmatian toadflax stems in 4 blocks of 8 treatments per site, were randomly selected for the duration of the study. Adult stem clusters selected for data collection were marked with 2 pieces of rebar at the NW and $\mathrm{SE}$ corners of the quadrat. A portable quadratframe consisting of a $60 \times 60 \mathrm{~cm}$ square divided into $9,20 \times 20 \mathrm{~cm}$ squares, was used to demarcate the observation arena. The frame had adjustable legs at each corner, which could extend to $30 \mathrm{~cm}$ in height to minimize plant disturbance during frame placement and removal.

During data collection, the frame was situated so that it laid between the 2 rebar stakes, with a designated side facing north. Data were collected on a weekly basis during 1997 and on a 7 to 14 day schedule in 1998. Data collected included seedling, stem (data not presented), and seed capsule counts (data not presented). Such data were collected within the $20 \times 20 \mathrm{~cm}$ center square and the 4 quadrants located in each cardinal direction. Plant data collected from the 4 quadrants and the 1 center square were averaged to generate mean weekly counts.

Seedlings were sorted into 3 classes of counts to keep track of weekly mortality and emergence events. The first class consisted of seedlings with 1-2 nodes beyond the cotyledon, the second of seedlings 2-5 nodes beyond the cotyledon, and the third of seedlings with more than 5 nodes beyond the cotyledon. Stems were marked with plastic ties to maintain a census through time and to help orient the frame. Two colors of plastic ties were used, 1 for the center square and 1 for each of the 4 squares located in each cardinal position. Finally, seed capsules were harvested from similar plants near each quadrat in 1997 and seeds counted in order to determine a realistic overseeding rate.

\section{Overseeding rate calculation and field application}

Experimental plots were supplementary seeded to address the question of whether or not seed abundance was the primary factor limiting Dalmatian toadflax seedling recruitment (Louda et al. 1990, Louda and Potvin 1995, Crawley 1989). Overseeding rate was calculated by averaging the total number of seed capsules from each quadrat at each site and multiplying the resulting mean by the mean number of seeds per capsule. The higher of the 2 site-means was taken and multiplied by a factor of 2 to generate an artificially high seeding rate of 92,192 seeds per quadrat, which was applied to both sites in the Fall of 1997.

Overseeding took place immediately following the last sampling date. Fall 1997 was selected as the overseeding time period so that seeds would be exposed to normal post-dispersal predation and mortality factors. Seeds were collected adjacent to the research plots at the 2 sites in the weeks immediately prior to seeding. Only seeds collected from a given site were used in the experimental treatments for that site. Seeds were scattered by hand from approximately $20 \mathrm{~cm}$ above the soil surface, using the quadrat frame as a guide, in an alternating $\mathrm{E}$ to $\mathrm{W}, \mathrm{W}$ to $\mathrm{E}$ zigzag running from the $\mathrm{N}$ to $\mathrm{S}$ sides of the quadrat frame.

A seedling emergence trial was performed in 1999 on seeds collected from either site in 1997 and 1998 to ascertain an approximate seed dormancy figure. Seeds were stored in darkness at room temperature, beginning immediately after collection. In the spring of 1999 seeds were 
placed on filter paper disks on thermal bars set for $18^{\circ} \mathrm{C}$ to maximize Dalmatian toadflax seedling emergence (Robocker 1970, 1974, Nowierski, et al. unpublished data). Each bar was equipped with a plexiglass shield and filter paper disks were moistened twice a day with distilled water to maintain constant water availability. Bars were set up with 2 disks per date/site combination with 40 seeds per disk providing 8 total replicates, for each date and site. Seedlings were counted and removed on a daily basis until there were 3 consecutive days without emergence. Temperatures were taken for each disk every 3 days to identify possible temperature effects between disks.

\section{Plant competition exclusion techniques}

Interspecific plant competition was excluded from half of the experimental quadrats to ascertain whether or not plant competition had an effect on Dalmatian toadflax seedling recruitment. Plant competition was excluded through a combination of careful pruning and herbicide application. After the quadrats had been mapped out and the frame set in place, Roundup ${ }^{\circledR}$ (N-Phosphonomethylglycine) was applied at the lowest labeled rate to interspecific competitors located around the outside of the quadrat through the use of a paintbrush, with care taken not to paint any toadflax plants. Roundup ${ }^{\circledR}$ was applied in a similar manner to large interspecific competitors (i.e., O. polyacantha, E. esula, $Y$. glauca, A. artemisiifolia, and M. officinalis) within the quadrats to more

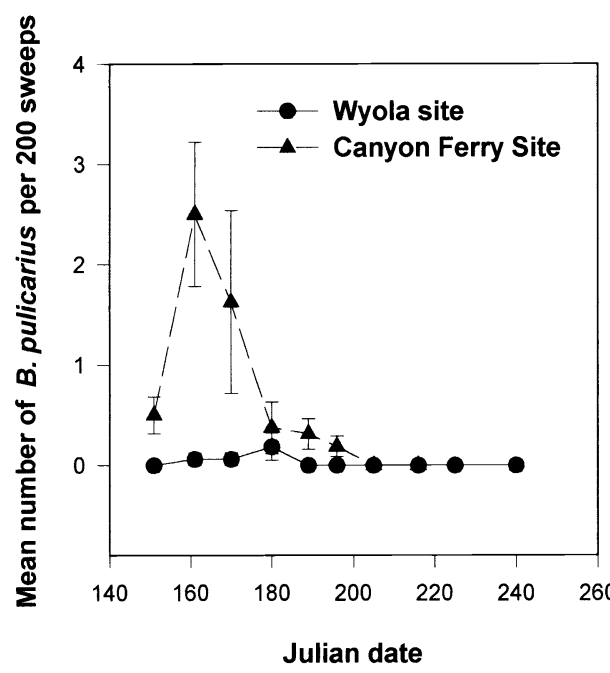

Fig. 1. Mean number of $B$. pulicarius caught per 50 sweeps at the Canyon Ferry and Wyola field sites during 1998. Error bars represent the standard error of the mean. completely remove them. Herbicide application was done only in the 1997 season within the first month (12 May to 15 June, 1997) of initial establishment of the quadrats. Above ground plant competition was further excluded through careful pruning of competitors at the soil surface. Pruning was done at every sampling period to minimize interspecific competition within the plant competition-excluded quadrats. Senescent toadflax stems from prior seasons were removed from all quadrats to facilitate frame placement.

\section{Natural enemy augmentation, exclu-} sion, and presence measurements

Augmentative releases of $B$. pulicarius were made at each of the 2 research sites to supplement low populations of the beetle and enhance the anticipated negative effects of the beetle on the growth and reproduction of Dalmatian toadflax. Adult B. pulicarius, collected from Dalmatian toadflax in British Columbia, were released at the 2 research sites during the weeks of 7 June 1997 and 10 June 1998. Four hundred adult $B$. pulicarius were released in each beetle treatment plot during 1997 and 1998. Beetle- excluded treatments received no beetles.

An insecticide treatment was applied to the beetle exclusion plots to exclude the effects of $B$. pulicarius. Orthene Isotox ${ }^{\circledR}$ (O,S-dimethyl acetylphos-phoramidothioate) was selected as the insecticide for natural enemy exclusion because it has a systemic residual action, demonstrates a low general phyto-toxicity, and has been used in similar experiments with no demonstrable effects on plant pollination rates (Louda 1982, Louda et al. 1990, Louda and Potvin 1995). Orthene was applied at a rate of $15 \mathrm{ml}$ pesticide per $350 \mathrm{ml}$ of water. Plants were sprayed using a hand-operated squirt bottle type sprayer, and applied from all sides of the plant to runoff. Plants in non-insecticide treatments were sprayed with distilled water in an identical fashion. Pesticide was applied every 14 to 20 days, until plants senesced. A phytotoxicity trial was conducted in the Montana State University Plant Growth Center during the winter of 1998-99 to assess whether Orthene had any effects on Dalmatian toadflax growth and flower production

During the 1998 growing season insect sweep samples were taken at approximate biweekly intervals in an attempt to quantify the population of $B$. pulicarius at both sites. Sweeps were performed with a standard insect sweep net and consisted of 4 sets of 200 sweeps per block. Samples were taken back to the lab and kept in a freezer until they were processed and mean beetle counts were determined. The mean number of $B$. pulicarius obtained in 1998 from the sweep net samples from the 2 sites is shown in Figure 1.

\section{Analysis}

Data were analyzed using a $2 \times 2 \times 4$ factorial ANOVA for the 1997 data and a $2 \times 2 \times 2 \times 4$ factorial ANOVA for the 1998 data. The ANOVA focused on 4 measurements related to seedling emergence, recruitment and production. Total seedling counts and cumulative seedling emergence data were transformed using a square root transformation and a natural $\log$ transformation $(\ln (\mathrm{x}+1))$, respectively, to normalize the data for parametric analysis. Both sites and years were analyzed separately, yielding results from 4 sets of analyses.

The SAS Statistical Package (SAS 1997) was used for all data analyses using the GLM procedure. All ANOVA models were reduced to include only factor effects and 2-way interaction effects with higher order interaction effects included in the overall MSE. Previous analyses indicated that there were no significant 3 or 4-way interactions. Significant 2 -way interactions were analyzed using a t-test to compare each possible pairing of 2-way factor combinations.

\section{Results}

\section{Total seedling counts on the last sampling date, 1997}

Although seeds germinate and produce seedlings over the course of the growing season, only those seedlings that survive until the end of the growing season may contribute to next year's toadflax population. Hence, we restricted the analysis to total seedling counts found among treatments on the last sampling date. The results of ANOVA of the mean total number of Dalmatian toadflax seedlings obtained across treatments on the final sampling date in 1997 for the Canyon Ferry and Wyola sites are presented in Table 2. Factor, block, and 2-way factor interaction means \pm standard errors are presented in Table 3 to corroborate the direction of statistically significant results. Significant differences in total seedling counts were found among blocks for both study sites $(P=0.019$ and $P=0.033$, respectively; Table 2 ). Although no differences in total seedling counts were found among treatments for the Canyon Ferry 
Table 2. Results of ANOVA of the total seedling count on the last sampling date for the Canyon Ferry and Wyola sites, 1997 . $^{\text {abc }}$

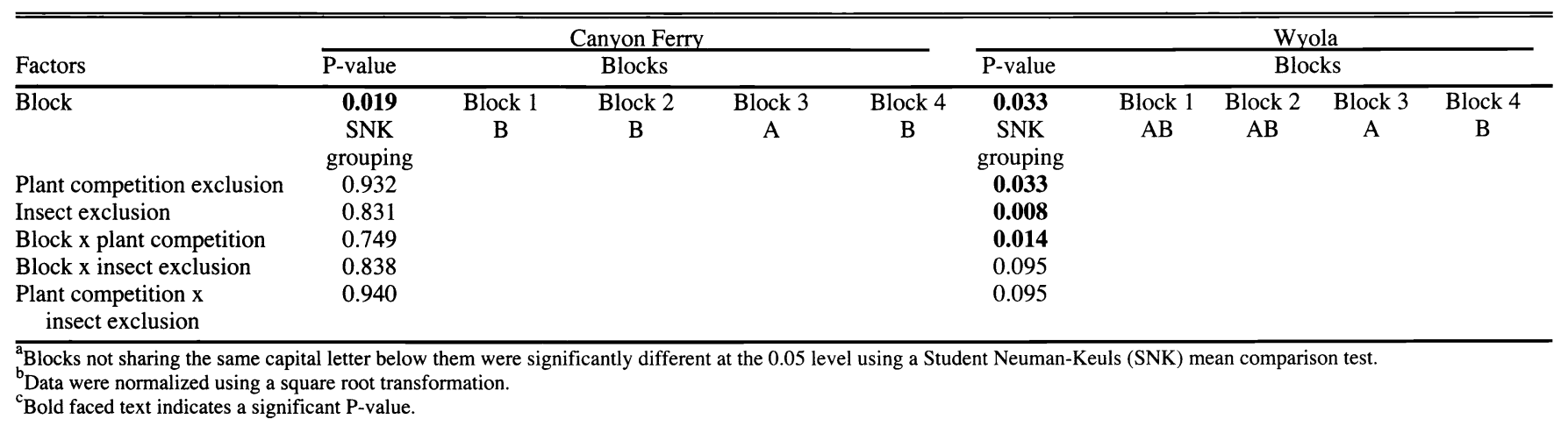

site $(P>0.05)$, significantly higher seedling counts were found for the Wyola site when either plant competition or insects were excluded $(\mathrm{P}=0.033$ and $\mathrm{P}=$ 0.008 , respectively; Table 2$)$. In addition, a significant block $\mathrm{x}$ plant competition interaction was found for total seedling counts from the Wyola site $(P=0.014)$.

\section{Total seedling counts on the last sampling date, 1998}

Unlike the previous year, no differences in total seedling counts were found among blocks in 1998 for both the Canyon Ferry and Wyola study sites ( $P>0.05$; Table 4$)$. As anticipated, plant competition significantly decreased the total seedling counts on the final sampling date for both the Canyon Ferry and Wyola research sites ( $\mathrm{P}$ $=0.005$ and $\mathrm{P}=0.010$, respectively; Table 4). However, overseeding and insect exclusion were found to have no influence on the total seedling counts obtained on the last sampling date for both research sites ( $P>0.05$; Table 4). Factor, block, and 2-way factor interaction means \pm standard errors are presented in Table 5 to corroborate direction of statistically significant results.

\section{Cumulative seedling counts on the last sampling date, 1997}

The results from ANOVA of the mean cumulative number of Dalmatian toadflax seedlings obtained across treatments on the final sampling date in 1997 for the Canyon Ferry and Wyola sites are presented in Table 4. A significant block effect was found for cumulative seedling counts at the Canyon Ferry site in 1997 ( $\mathrm{P}=$ 0.005 ), while no differences were found among blocks at the Wyola site in 1997 (P $>0.05$; Table 6). Except for a significant block $x$ plant competition interaction at the Wyola site $(P=0.04$; Table 6$)$, the exclusion of plant competition and insects had no effects on cumulative seedling emergence ( $P>0.05$; Table 6$)$. Factor, block, and 2-way factor interaction means \pm standard errors are presented in Table 3

Table 3. Factor means \pm standard errors for ANOVA of the total seedling count and cumulative seedling emergence on the last sampling date for the Canyon Ferry and Wyola sites, 1997. ${ }^{\mathrm{a}}$

\begin{tabular}{|c|c|c|c|c|}
\hline Factors & Mean $\pm \mathrm{SE}$ & Mean $\pm \mathrm{SE}$ & Mean \pm SE & Mean $\pm \mathrm{SE}$ \\
\hline Parameter & \multicolumn{2}{|c|}{ Total seedling count } & \multicolumn{2}{|c|}{$\begin{array}{c}\text { Cumulative seedling } \\
\text { emergence }\end{array}$} \\
\hline Site & Canyon Ferry & Wyola & Canyon Ferry & Wyola \\
\hline Block 1 & $0.35 \pm 0.13$ & $0.55 \pm 0.33$ & $1.40 \pm 0.28$ & $12.83 \pm 4.52$ \\
\hline Block 2 & $0.50 \pm 0.21$ & $0.40 \pm 0.19$ & $2.00 \pm 0.58$ & $5.6 \pm 2.82$ \\
\hline Block 3 & $2.6 \pm 1.06$ & $0.88 \pm 0.26$ & $8.43 \pm 2.50$ & $7.08 \pm 1.05$ \\
\hline Block 4 & $0.38 \pm 0.14$ & $0.20 \pm 0.08$ & $1.88 \pm 0.35$ & $2.58 \pm 0.76$ \\
\hline Plant competition allowed & $1.13 \pm 0.58$ & $0.35 \pm 0.15$ & $3.80 \pm 1.46$ & $5.68 \pm 1.51$ \\
\hline Plant competition excluded & $0.79 \pm 0.26$ & $0.65 \pm 0.18$ & $3.05 \pm 0.74$ & $8.36 \pm 2.52$ \\
\hline Insects allowed & $0.79 \pm 0.27$ & $0.24 \pm 0.07$ & $1.38 \pm 0.81$ & $5.91 \pm 1.91$ \\
\hline Insects excluded & $1.13 \pm 0.57$ & $0.76 \pm 0.21$ & $3.48 \pm 1.43$ & $8.13 \pm 2.25$ \\
\hline Plant comp. allowed $\mathrm{x}$ insects allowed & $0.75 \pm 0.29$ & $0.20 \pm 0.09$ & $3.68 \pm 1.19$ & $4.20 \pm 1.07$ \\
\hline Plant comp. allowed $\mathrm{x}$ insects excluded & $1.50 \pm 1.1$ & $0.50 \pm 0.29$ & $3.93 \pm 2.77$ & $7.15 \pm 2.84$ \\
\hline Plant comp. excluded $\mathrm{x}$ insects allowed & $0.83 \pm 0.48$ & $0.28 \pm 0.11$ & $3.08 \pm 1.17$ & $7.63 \pm 3.70$ \\
\hline Plant comp. excluded $\mathrm{x}$ insects excluded & $0.75 \pm 0.23$ & $1.03 \pm 0.30$ & $3.03 \pm 1.00$ & $9.10 \pm 3.65$ \\
\hline
\end{tabular}

to corroborate direction of statistically significant results.

\section{Cumulative seedling counts on the last sampling date, 1998}

As in 1997, significant differences in cumulative seedling numbers were found among blocks for the Canyon Ferry site in 1998 ( $\mathrm{P}=0.029)$, but not for the Wyola research site $(P>0.05$; Table 7$)$. Significantly higher cumulative seedling counts were found for both the Canyon Ferry and Wyola sites in 1998 when plant competition was excluded $(\mathrm{P}=0.021$ and $\mathrm{P}=0.005$, respectively; Table 7). As was found in 1997, insect exclusion had no effect on cumulative seedling numbers at both research sites $(\mathrm{P}>0.05)$. All interactions were nonsignificant $(\mathrm{P}>0.05$; Table 7). Factor, block, and 2-way factor interaction means \pm standard errors are presented in Table 5 to corroborate direction of statistically significant results.

\section{Seedling emergence trial results}

Mean temperatures recorded across replicates were statistically similar. Mean percent emergence \pm standard error for seed collected from Wyola 1997 (0.71 \pm $0.05)$, Wyola $1998(0.66 \pm 0.05)$, and Canyon Ferry $1997(0.69 \pm 0.04)$ were statistically similar $(\mathrm{P}>0.05)$. However mean percent emergence was statistically lower for Canyon Ferry 1998 (0.28 \pm 0.05$)$ seed compared to the other 3 seed collections $(\mathrm{P}=0.0001)$.

\section{Discussion and Conclusions}

A widely accepted approach for testing seed versus microsite limitation of seedling recruitment is to compare natural seedling population dynamics with situations where unnaturally high quantities of seed are added (Crawley and Nachapong 
Table 4. Results of ANOVA of the total seedling count on the last sampling date for the Canyon Ferry and Wyola sites, 1998 . $^{\text {abc }}$

\begin{tabular}{|c|c|c|c|c|c|c|c|c|c|c|}
\hline \multirow{3}{*}{$\begin{array}{l}\text { Factors } \\
\text { Block }\end{array}$} & \multicolumn{5}{|c|}{ Canyon Ferry } & \multicolumn{5}{|c|}{ Wyola } \\
\hline & \multicolumn{2}{|l|}{ P-value } & \multicolumn{3}{|l|}{ Blocks } & \multirow{2}{*}{$\begin{array}{c}\text { P-value } \\
0.069\end{array}$} & \multicolumn{4}{|c|}{ Blocks } \\
\hline & 0.067 & Block 1 & Block 2 & Block 3 & Block 4 & & Block 1 & Block 2 & Block 3 & Block 4 \\
\hline & $\begin{array}{l}\text { SNK } \\
\text { grouping }\end{array}$ & A & A & A & A & $\begin{array}{l}\text { SNK } \\
\text { grouping }\end{array}$ & A & A & A & A \\
\hline Overseeding & 0.875 & & & & & 0.281 & & & & \\
\hline Plant competition & 0.005 & & & & & 0.010 & & & & \\
\hline Insect exclusion & 0.360 & & & & & 0.431 & & & & \\
\hline Block $\mathrm{x}$ overseeding & 0.967 & & & & & 0.260 & & & & \\
\hline Block x plant competition & 0.204 & & & & & 0.069 & & & & \\
\hline Block $\mathrm{x}$ insect exclusion & 0.843 & & & & & 0.170 & & & & \\
\hline Overseeding $\mathrm{x}$ plant competition & 0.695 & & & & & 0.281 & & & & \\
\hline Overseeding $\mathrm{x}$ insect exclusion & 0.128 & & & & & 0.837 & & & & \\
\hline Plant competition $\mathrm{x}$ insect exclusion & 0.871 & & & & & 0.431 & & & & \\
\hline
\end{tabular}

${ }_{\mathrm{a}}^{\mathrm{B}}$ Blocks not sharing the same capital letter below them were significantly different at the 0.05 level using a Student Neuman-Keuls (SNK) mean comparison test.

${ }^{\mathrm{b}}$ Data were normalized using a square root transformation.

${ }^{c}$ Bold faced text indicates a significant P-value.

1985, Crawley 1988, Louda et al. 1990, Louda and Potvin 1995). However, seedlings do not recruit into an ecological vacuum; seed producing plants, seeds, and seedlings are all subject to plant competition as well as the effects of herbivores, microorganisms, and other factors (Nowierski et al. 1999). In light of this, it is important to understand that seed and microsite limitation are not mutually exclusive; instead they are dependent parts of the weeds biotic and abiotic environment (Eriksson and Ehlen 1991).

Ecological management of rangeland weeds includes the use of natural enemies as predators of weeds as well as the use of more desirable plant species as competitors (Kennett et al. 1992, Sheley et al. 1996, Lym et al. 1997). One biological strategy for managing a target weed is to reduce seed production to a point where adult mortalities cease to be replaced by new recruits. Likewise, plant communities that limit the availability of seedling emergence safe sites or provide heavy competition for resources may be able to limit the recruitment of new seedlings into a weed population (Velagala et al. 1997, Sheley et al. 1999). Both approaches limit the recruitment of the weed albeit by influencing different aspects of the system.

In the case of Dalmatian toadflax, overseeding did not appear to significantly affect seedling recruitment for the first year toadflax population. The enhancement of the seed supply for the 1998 growing season was not a significant factor in last date seedling counts nor cumulative seedling emergence. This suggests that under the field conditions that occurred during our 2-year field study, the Dalmatian toadflax populations at the 2 sites filled most "safe seedling emergence sites". Results obtained from the seedling emergence trial were consistent $(66-71 \%)$ with results obtained in previous studies for similar aged seeds with the exception of seeds collected in 1998 from Canyon Ferry (Robocker 1970, Nowierski et al. unpublished data). It is therefore possible that a greater portion of seeds added to the Canyon Ferry site may have remained dormant.

It is important to note that belowground interspecific plant competition may have still been a factor in plant competition allowed treatments. While the larger competitors were treated with roundup, the smaller competitors were not, and may

have continued to compete for moisture after clipping. However, plant competition was the main factor affecting final seedling counts in 3 of 4 situations examined, suggesting that seedling recruitment of Dalmatian toadflax was limited by interspecific resource competition. Plant competition appeared to play less of a role in the cumulative number of seedlings recorded at the research sites, as significant effects from competition were found in only half of the situations examined.

Herbivory by insects appeared to exert only a minor influence on the final

Table 5. Factor means \pm standard errors for total seedling count and cumulative seedling emergence on the last sampling date for the Canyon Ferry and Wyola sites, 1998 . $^{\text {a }}$

\begin{tabular}{|c|c|c|c|c|}
\hline Factors & Mean $\pm \mathrm{SE}$ & Mean $\pm S E$ & Mean $\pm S E$ & Mean \pm SE \\
\hline Parameter & \multicolumn{2}{|c|}{ Total seedling count } & \multicolumn{2}{|c|}{ Cumulative seedling emergence } \\
\hline Site & Canyon Ferry & Wyola & Canyon Ferry & Wyola \\
\hline Block 1 & $0.40 \pm 0.17$ & $0.05 \pm 0.05$ & $3.43 \pm 2.29$ & $6.85 \pm 3.77$ \\
\hline Block 2 & $0.53 \pm 0.2$ & $0.00 \pm 0.00$ & $4.23 \pm 2.59$ & $7.00 \pm 3.22$ \\
\hline Block 3 & $1.93 \pm 0.66$ & $0.10 \pm 0.0$ & $12.00 \pm 2.4$ & $6.45 \pm 2.26$ \\
\hline Block 4 & $0.68 \pm 0.20$ & $0.95 \pm 0.76$ & $2.80 \pm 0.76$ & $16.75 \pm 6.60$ \\
\hline Non-overseeded & $1.00 \pm 0.38$ & $0.46 \pm 0.39$ & $4.21 \pm 1.56$ & $7.99 \pm 3.28$ \\
\hline Overseeded & $0.76 \pm 0.18$ & $0.09 \pm 0.05$ & $7.01 \pm 1.86$ & $10.54 \pm 2.93$ \\
\hline Plant competition allowed & $0.38 \pm 0.13$ & $0.00 \pm 0.00$ & $2.99 \pm 1.10$ & $2.96 \pm 0.87$ \\
\hline Plant competition excluded & $1.39 \pm 0.36$ & $0.55 \pm 0.38$ & $8.24 \pm 2.01$ & $15.56 \pm 3.68$ \\
\hline Insects allowed & $0.83 \pm 0.29$ & $0.46 \pm 0.39$ & $6.43 \pm 2.00$ & $10.54 \pm 3.74$ \\
\hline Insects excluded & $0.94 \pm 0.30$ & $0.09 \pm 0.04$ & $4.80 \pm 1.44$ & $7.99 \pm 2.33$ \\
\hline Non-overseeded x plant comp. allowed & $0.40 \pm 0.16$ & $0.00 \pm 0.00$ & $2.13 \pm 0.61$ & $2.03 \pm 0.61$ \\
\hline Non-overseeded x plant comp. excluded & $1.60 \pm 0.69$ & $0.93 \pm 0.76$ & $6.30 \pm 2.98$ & $13.95 \pm 5.97$ \\
\hline Overseeded x plant comp. allowed & $0.35 \pm 0.20$ & $0.00 \pm 0.00$ & $3.85 \pm 2.14$ & $3.90 \pm 1.62$ \\
\hline Overseeded x plant comp. excluded & $1.18 \pm 0.23$ & $0.18 \pm 0.10$ & $10.18 \pm 2.71$ & $17.18 \pm 4.66$ \\
\hline Non-overseeded $\mathrm{x}$ insects allowed & $0.75 \pm 0.52$ & $0.78 \pm 0.78$ & $3.63 \pm 2.20$ & $11.28 \pm 6.43$ \\
\hline Non-overseeded $\mathrm{x}$ insects excluded & $1.25 \pm 0.57$ & $0.15 \pm 0.08$ & $4.80 \pm 2.36$ & $4.70 \pm 1.32$ \\
\hline Overseeded $\mathrm{x}$ insects allowed & $0.85 \pm 0.32$ & $0.15 \pm 0.11$ & $8.45 \pm 3.08$ & $7.65 \pm 4.43$ \\
\hline Overseeded $\mathrm{x}$ insects excluded & $0.73 \pm 0.15$ & $0.03 \pm 0.03$ & $3.85 \pm 1.15$ & $11.55 \pm 4.21$ \\
\hline Plant comp. allowed $\mathrm{x}$ insects allowed & $0.40 \pm 0.24$ & $0.00 \pm 0.00$ & $2.68 \pm 1.60$ & $3.60 \pm 1.62$ \\
\hline Plant comp. allowed $\mathrm{x}$ insects excluded & $0.35 \pm 0.10$ & $0.00 \pm 0.00$ & $3.30 \pm 1.60$ & $2.33 \pm 0.71$ \\
\hline Plant comp. excluded $\mathrm{x}$ insects allowed & $1.25 \pm 0.51$ & $0.93 \pm 0.76$ & $10.18 \pm 3.24$ & $17.48 \pm 6.59$ \\
\hline Plant comp. excluded $\mathrm{x}$ insects excluded & $1.53 \pm 0.53$ & $0.18 \pm 0.08$ & $6.30 \pm 2.40$ & $13.65 \pm 3.68$ \\
\hline
\end{tabular}

${ }^{a}$ Bold faced text indicates a significant factor or interaction $(\alpha=0.05)$. 
Table 6. Results of ANOVA of the cumulative seedling emergence on the last sampling date for the Canyon Ferry and Wyola sites, 1997 . $^{\text {abc }}$

\begin{tabular}{|c|c|c|c|c|c|c|c|c|c|c|}
\hline \multirow{3}{*}{$\frac{\text { Factors }}{\text { Block }}$} & \multicolumn{5}{|c|}{ Canyon Ferry } & \multicolumn{5}{|c|}{ Wyola } \\
\hline & \multicolumn{2}{|l|}{$\overline{\mathrm{P} \text {-value }}$} & \multicolumn{3}{|c|}{ Blocks } & \multicolumn{2}{|l|}{$\bar{P}$-value } & \multicolumn{2}{|c|}{ Blocks } & \multirow{3}{*}{$\begin{array}{c}\text { Block } 4 \\
\text { A }\end{array}$} \\
\hline & 0.005 & Block 1 & Block 2 & Block 3 & Block 4 & 0.052 & Block 1 & Block 2 & Block 3 & \\
\hline & $\begin{array}{c}\text { SNK } \\
\text { grouping }\end{array}$ & B & B & A & B & $\begin{array}{l}\text { SNK } \\
\text { grouping }\end{array}$ & A & A & A & \\
\hline Plant competition exclusion & 0.876 & & & & & 0.424 & & & & \\
\hline Insect exclusion & 0.435 & & & & & 0.383 & & & & \\
\hline Block $\mathrm{x}$ plant competition & 0.900 & & & & & 0.041 & & & & \\
\hline Block $\mathrm{x}$ insect exclusion & 0.905 & & & & & 0.607 & & & & \\
\hline Plant competion & & & & & & & & & & \\
\hline $\mathrm{x}$ insect exclusion & 0.367 & & & & & 0.684 & & & & \\
\hline
\end{tabular}

${ }^{a}$ Blocks not sharing the same capital letter below them were significantly different at the 0.05 level using a Student Neuman-Keuls (SNK) mean comparison test.

${ }^{b}$ Data were normalized using a square root transformation.

${ }^{\mathrm{c}}$ Bold faced text indicates a significant $\mathrm{P}$-value.

Table 7. Results of ANOVA of the cumulative seedling emergence on the last sampling date for the Canyon Ferry and Wyola sites, $1998 .^{\text {abc }}$

\begin{tabular}{|c|c|c|c|c|c|c|c|c|c|c|}
\hline \multirow{2}{*}{ Factors } & \multicolumn{5}{|c|}{ Canyon Ferry } & \multicolumn{5}{|c|}{ Wyola } \\
\hline & $\overline{\mathrm{P} \text {-value }}$ & & Blocks & & & $\overline{\text { P-value }}$ & & Blo & & \\
\hline$\overline{\text { Block }}$ & $\begin{array}{l}\mathbf{0 . 0 2 9} \\
\text { SNK } \\
\text { grouping }\end{array}$ & $\begin{array}{c}\text { Block } 1 \\
\text { B }\end{array}$ & $\begin{array}{c}\text { Block } 2 \\
\text { B }\end{array}$ & $\begin{array}{c}\text { Block } 3 \\
\text { A }\end{array}$ & $\begin{array}{c}\text { Block } 4 \\
\text { B }\end{array}$ & $\begin{array}{l}0.498 \\
\text { SNK } \\
\text { grouping }\end{array}$ & $\begin{array}{c}\text { Block } 1 \\
\text { A }\end{array}$ & Block 2 & $\begin{array}{c}\text { Block } 3 \\
\text { A }\end{array}$ & $\begin{array}{c}\text { Block } 4 \\
\text { A }\end{array}$ \\
\hline Overseeding & 0.299 & & & & & 0.459 & & & & \\
\hline Plant competition & 0.021 & & & & & 0.041 & & & & \\
\hline Insect exclusion & 0.943 & & & & & 0.929 & & & & \\
\hline Block $\mathrm{x}$ overseeding & 0.940 & & & & & 0.937 & & & & \\
\hline Block x plant competition & 0.705 & & & & & 0.434 & & & & \\
\hline Block $\mathrm{x}$ insect exclusion & 0.875 & & & & & 0.777 & & & & \\
\hline $\begin{array}{l}\text { Overseeding } \mathrm{x} \text { plant } \\
\text { competition }\end{array}$ & 0.228 & & & & & 0.992 & & & & \\
\hline Overseeding $\mathrm{x}$ insect exclusion & 0.246 & & & & & 0.728 & & & & \\
\hline $\begin{array}{l}\text { Plant competition } \mathrm{x} \\
\text { insect exclusion }\end{array}$ & 0.425 & & & & & 0.652 & & & & \\
\hline
\end{tabular}

${ }^{\mathrm{a}}$ Blocks not sharing the same capital letter below them were significantly different at the 0.05 level using a Student Neuman-Keuls (SNK) mean comparison test.

${ }^{\mathrm{b}}$ Data were normalized using a square root transformation.

${ }^{c}$ Bold faced text indicates a significant P-value

seedling counts, and no influence on final cumulative seedling counts. However, the minimal impact from $B$. pulicarius likely resulted from the extremely low population levels of the beetles present at both sites, even following supplemental releases of the beetle at the sites. Neither site averaged even 1 beetle per sweep in 1998, and peak beetle catches were obtained following supplemental beetle releases at both sites.

Notwithstanding the low B. pulicarius populations at the 2 research sites, other studies have documented the relatively negligible effects of herbivory from insects on the reproductive tissues of microsite-limited plants (Crawley 1989, Crawley and Gillman 1989, Eriksson and Ehrlen 1991, Paynter et al. 1996).

Based on the results obtained in this study we conclude that seedling recruitment in Dalmatian toadflax is more commonly limited by interspecific competition for microsites, than by seed availability, which in view of the plant's life history seems plausible. The potential of Dalmatian toadflax for producing large numbers of small seeds, coupled with its vegetative mode of reproduction would seem to limit the importance of individual seedling recruitment in maintaining an established population (Robocker 1970, 1974). The large quantities of seed that the plant produces may also enable the plant to compensate for pre- and post- dispersal seed predation.

Accepting this conclusion means that limiting seed in existing patches of Dalmatian toadflax through the attack of reproductive structures is unlikely to result in a reduction of stand density. Similar conclusions have been reached for tansy ragwort by Crawley and Nachapong (1985) and Crawley and Gillman (1989). Successful management of Dalmatian toadflax will most likely depend on limiting adult stem and lateral root-bud production. This could be accomplished through the establishment of natural enemies that feed on stem or root structures of Dalmatian toadflax, selective herbicide application timed to affect only Dalmatian toadflax stems or over-wintering rosettes, and the encouragement of healthy, desirable plant populations that provide strong competition for resources. Selective herbi- cides applied at a responsible rate and during appropriate times in the plant and natural enemies' life cycles could potentially augment the effectiveness of biological control. Grazing, in concert with other management strategies, has been shown to have a significant impact on the stand densities of leafy spurge and spotted knapweed (Lacey and Sheley 1996, Lym et al. 1997, Maxwell et al. 1992). Hence, it is conceivable that grazing and cultural control strategies could play an important role in the management of Dalmatian toadflax. In conclusion we believe that the integration of weed management strategies mentioned above, along with the maintenance of a healthy plant community, will likely provide the greatest opportunities for the sustainable management of this troublesome weed in the future.

\section{Literature Sited}

Alex, J. F. 1962. The taxonomy, history, and distribution of Linaria dalmatica. Can. J. Bot. 40:295-307. 
Bossard, C. C. and M. Rejmanek. 1994. Herbivory, growth, seed production, and resprouting of an exotic invasive shrub. Biolog. Conserv. 67:193-200.

Burger, J. C. and S. M. Louda 1995. Interaction of diffuse competition and inset herbivory in limiting brittle prickly pear cactus, Opuntia fragilis (Cactaceae). Am. J. Bot. 82:1558-1566.

Crawley, M. J. 1988. Herbivores and plant population dynamics, p. 367-392. In: A.J. Davy, M.J. Hutchings, and A.R. Watkinson (eds.) Plant population ecology: the $28^{\text {th }}$ symposium of the British Ecological Society, Sussex 1988. Blackwell Scientific Publication, Oxford.

Crawley, M. J. and M. P. Gillman. 1989. Population dynamics of cinnabar moth and ragwort in grassland. J. Animal Ecol. 58: 1035-1050.

Crawley, M. J. and M. Nachapong. 1985. The establishment of seedlings from primary and regrowth seeds of ragwort (Senacio jacoboea). J. Ecol. 73:255-261.

Eriksson, O. and J. Ehlen. 1991. Seed and microsite limitation of recruitment in plant populations. Oecologia 91: 360-364.

Gross, K. L. and P. A. Werner. 1982. Colonizing abilities of biennial plant species in relation to ground cover: implications for their distributions in a successional sere. Ecol. 63:921-931.

Grubb, R.T. 1998. Effects of Brachypterolus pulicarius on growth and seed production of Dalmatian toadflax. Masters Thesis, Montana State Univ., Bozeman, Mont..

Hendrix, S. D. and E. J. Trapp. 1989. Floral herbivory in Pastinaca sativa: do compensatory responses offset reductions in fitness? Evolution 43:891-895.

Jeanneret, P. and D. Schroeder. 1992. Biology and host specificity of Mecinus janthinus Germar (Col.: Curculionidae), a candidate for the biological control of yellow and Dalmatian toadflax, Linaria vulgaris (L.) Mill. And Linaria dalmatica (L.) Mill. (Scrophulariaceae) in North America. Biocontrol Sci. Technol. 2:25-34.

Kennett, G. A., J. R. Lacey, C. A. Butt, K. M. Olson-Rutz, and M. R. Haferkamp. 1992. Effects of defoliation, shading and competition on spotted knapweed and bluebunch wheatgrass. J. Range Manage. 45: 363-69.

Lacey, J. R. and R. L. Sheley. 1996. Leafy spurge and grass response to picloram and intensive grazing. J. Range Manage. 49:311-314.

Lajeunesse, S. E., P. K. Fay, J. R. Lacy, R. M. Nowierski, D. Zamora, and D. Cooksey. 1993. Dalmatian Toadflax-a weed of pasture and rangeland: Identification, biology, and management. Montana Agr. Exp. Sta. Bull. 115

Louda S. M. 1982. Limitation of the recruitment of the shrub Haplopappus squarrosus (Asteraceae) by flower and seed-feeding insects. J. Ecol. 70:43-53.
Louda, S. M. and M. A. Potvin. 1995. Effect of inflorescence-feeding insects on the demography and lifetime fitness of a plant. Ecol.. 76:229-245.

Louda S. M., M. A. Potvin and S. K. Collinge. 1990. Predispersal seed predation, post-dispersal seed predation and competition in the recruitment of seedlings of a native thistle in sandhills prairie. Amer. Midl. Nat. 124:105-113.

Lym, R. G., K. K. Sedivec, and D. R. Kirby. 1997. Leafy spurge control with angora goats and herbicides. J. Range Manage. 50:123-128.

Maxwell, J. F., R. Drinkwater, D. Clark, and J. W. Hall. 1992. Effect of grazing, spraying, and seeding on knapweed in British Columbia. J. Range Manage. 45:180-82.

Nowierski, R. M. 1995. Dalmatian Toadflax, Linaria genistifolia spp. dalmatica (L.) Maire and Peritmengin (Scrophulariaceae), pp. 312-317. In: J.R. Nechols, L. A. Andres, J. W. Beardsley, R. D. Goeden, and C. G. Jackson [Eds.]. Biological control in the western states: accomplishments and benefits of regional research project W84 (1964-89), Univ. of Calif., Agr. And Natural Resources Publ. \#3361, Oakland, Calif.

Nowierski, R. M. 1996. Dalmatian toadflax In: Rees, N. E., P. C. Quimby, G. L. Piper, C. E. Turner, E. M. Coombs, N. R. Spencer, and L. V. Knutson (Eds.). Biological Control of Weeds in the West. Western Soc. Weed Sci. Bozeman , Mont., 9 pp

Nowierski, R. M., C. B. Huffaker, D. L. Dahlsten, D. K. Letourneau, D. H. Janzen, and G. G. Kennedy. 1999. The influence of insects on plant populations and communities, pp. 585-642. In: C. B. Huffaker and A P. Guitierrez [Eds.]. Ecological Entomology, $2^{\text {nd }}$ ed., John Wiley \& Sons, New York.

Paynter, Q. S. V. Fowler, H. L. Hinz, J. Memmott, R. Shaw, A. W. Sheppard, and P. Syrett. 1996. Pp. 495-501 in V. C. Moran and J. H. Hoffman [Eds.] Proc. IX Int. Symp. Biol. Contr. Weeds, 19-26 January, 1996, Stellenbosch, South Africa. Univ. of Cape Town.

Polunin, O. 1969. Flowers of Europe: a Field Guide. Oxford: Oxford University Press.

Putwain, P. D. and J. L. Harper. 1968. Studies in the dynamics of plant populations: II. Components and regulation of a natural population of Rumex Acetosella L. J. of Ecol. 56:421-431

Robocker, W. C. 1970. Seed characteristics and seedling emergence of Dalmatian toadflax. Weed Sci. 18:720-25.

Robocker, W. C. 1974. Life history, ecology, and control of Dalmatian toadflax. Washington Agr. Exp. Sta. Tech. Bull.

SAS Institute, 1997. SAS/STAT Software: Changes and Enhancements Through Release 6.12. Cary NC: SAS Institute.

Sheley, R. L., J. S. Jacobs, and R. P. Velagala. 1999. Enhancing intermediate wheatgrass establishment in spotted knapweed infested rangeland. J. Range Manage. 52:68-74
Sheley, R. L., T. J. Svejcar, and B. D. Maxwell. 1996. A theoretical framework for developing successional weed management strategies on rangeland. Weed Tech. 10:95-133.

Velagala, R. P., R. L. Sheley, and J. S. Jacobs. 1997. Influence of density on intermediate wheatgrass and spotted knapweed interference. J. Range Manage. 50:523-529.

Vujnovic, K. and R. W. Wein. 1997. The biology of Canadian weeds. 106. Linaria dalmatica (L.) Mill. Can. J. Plant Sci. 77:483-491. 